\title{
Delimitation of Maritime Boundary with India and Bangladesh's Rights over the Sea
}

\author{
Md. Mostofa ${ }^{1}$, Dewan Md. Al-Amin ${ }^{1}$ \& Kaniz Tania Bint-E-Basar ${ }^{1}$ \\ ${ }^{1}$ Department of Law, Faculty of Arts, Social Science \& Law, Bangladesh University, Bangladesh \\ Correspondence: Md. Mostofa, Department of Law, Faculty of Arts, Social Science \& Law, Bangladesh University, \\ Bangladesh, E-mail: mostofa.bu@gmail.com, Tel: +8801723084138
}

Received: May 12, 2018

Accepted: May 20, 2018

Online Published: June 7, 2018

\begin{abstract}
Bangladesh and India sea boundary talks started in 1974, renewed in 1978 and in 1982. At last, the Hauge-based Permanent Court of Arbitration (PCA) gave verdict on July 07, 2014 on maritime disputes between India and Bangladesh. In a landmark judgment, the Permanent Court of Arbitration (PCA) awarded Bangladesh an area of $19,467 \mathrm{sq} \mathrm{km}$, four-fifth of the total area of 25,602 sq km disputed maritime boundary in the Bay of Bengal with India. Now, Bangladesh's maritime boundary has been extended by $118,813 \mathrm{sq} \mathrm{km}$ comprising $12 \mathrm{~nm}$ of Territorial Sea and an EEZ extending up to $200 \mathrm{~nm}$ into the high sea. In addition, the ruling acknowledged Bangladesh's sovereign rights of undersea resources in the continental shelf extending as far as $345 \mathrm{~nm}$ in the high sea, taking Chittagong coast as the baseline. Now, Bangladesh can go ahead with their plans of search and extraction of energy and mineral resources and exploitation of fisheries within $200 \mathrm{~nm}$ from the baseline. The study tries to identify the various rights of Bangladesh over various maritime zones such as Territorial Sea, Contiguous Zone, Exclusive Economic Zone and Continental Shelf on the basis of the Bangladesh v India case (2014).
\end{abstract}

Keywords: Territorial sea, Contiguous zone, Exclusive economic zone, Continental shelf, PCA.

\section{Introduction}

Bangladesh and India sea boundary talks started in 1974, renewed in 1978 and in 1982; it could not be resolved because of the differences over methods of delimiting the boundary between the two sides. At last, The Permanent Court of Arbitration (PCA) at The Hague officially conveyed the result to both parties on 7 July 2014. On the basis of the judgment, 200 nautical miles Exclusive Economic Zone has been legally ensured for Bangladesh. It is a major achievement for Bangladesh. Now, Bangladesh owns more than 1, 18, $813 \mathrm{~km}$ of waters comprising Territorial Sea, Contiguous Zone and Exclusive Economic Zone. As a result, the rights in our different sea area have completely been ensured. According to the Convention and statutory law, Bangladesh must be able to exercise its legal rights on waters, living and non living resources in the Territorial Sea, Contiguous Zone, Exclusive Economic Zone and the Continental Shelf. The author tried to identify the various rights of Bangladesh over various maritime zones on the basis of the Bangladesh v India case (2014) and gave some applicable recommendations which will influence the Government.

2. Literature Review

The Law of the Sea has developed over the years, and is presently codified in the United Nations Convention on the Law of the Sea, 1982,1 which was the outcome of the Third United Nations Conference on the Law of the Sea (UNCLOS III). Basically, the Convention does not differ from the four previous Geneva Conventions, 1958,2 except that it extends jurisdiction of the coastal state over baselines, territorial sea, and the continental shelf and provides for a new sea zone such as the 200 nautical mile (n.m.) exclusive economic zone (EEZ). The delineation of sea zones gives rise to problems between adjacent and opposite states, and has created problems between Bangladesh and its adjacent neighbors-India and Burma. This study will deal with how Bangladesh designates different sea zones, and in particular the difficulties encountered in prescribing sea zones under UNCLOS III and in delimiting the zones between Bangladesh and its neighbors (Rahman, M. H., 1984). 
Sea-level rise is one of the certain consequences of climate change. Global mean sea level has been rising throughout the twentieth and twenty-first centuries. Furthermore, because of the lag in the oceans' response to warming, it is expected to continue to raise for centuries, even under the most optimistic mitigation scenarios. Projections of sea-level rise span a broad range. In its Fourth Assessment Report, the Intergovernmental Panel on Climate Change suggested 18-59 cm of global mean sea-level rise by 2100 compared with 1990 levels (plus an uncertain component from dynamic ice-sheet adjustment). Semi-empirical methods have since put forward values of $1.5 \mathrm{~m}$ and more3, 4. Irrespective of the actual level of sea-level rise by 2100 , future changes in the world's coastlines will pose fundamental new challenges, not least for international relations (Houghton, K. J, et.al. 2010).

3. Objectives of the Research

The following objectives are pursued

- To justify the claims of Bangladesh over various maritime zones.

- To identify the various rights of Bangladesh over various maritime zones with the convention, statutory law and case law.

- To offer some recommendations to government to ensure Bangladesh's rights.

4. Research Methodology

The author adopted 'Doctrinal Research Methodology'(Tewari, 2004) with 'Analytical Approach'(Faruque, 2009)to identify Ratio Decidendi of the case. Deductive legal reasoning of the case laws and Harvard reference style of Case Citation have been followed. Reasonable importance has been given to identify the various rights of Bangladesh on the sea (Halim, 2008). Case study has been taken as Empirical Tool, where relevant maritime delimitation case 2014 including existing agreements among state parties within the meaning of relevant Articles of the UNCLOS iii (1982).

5. Data Analysis and Interpretation

5.1 Bangladesh vs. India Case (2014) and the Judgment

Total disputed sea area between Bangladesh and India was 25,602 sq km in the Bay of Bangal. Bangladesh submitted its statement of claim by May 2011 to the Court of Arbitration. India submitted its counter-memorial by July 2012. Rejoinder of Bangladesh was lodged on 31st January and India's reply was submitted by 31st July 2013. Oral hearing from both sides were heard by the Arbitration Court in December 2013 (9th-18th).The Court of Arbitration consist of three jurist as Arbitrators -Tullio Treves of Italy, I.A Shearer of Australia and Rudigar Wolfrum of Germany and one each nominated by Bangladesh and India. Bangladesh nominated former judge Thomas Mensah from Ghana and India nominated D. P.Sreenivasa Rao, former legal adviser of the External Affairs Ministry. Five arbitrators comprise the court preside over by Rudigar Wolfrum of Germany. In July 2013Treves resigned and a French jurist Jean-Pierre Cot was appointed in his place in consultation with both parties. On behalf of India lawyers, RKP Shankardass, Alain Pellet, Michael Reisman and Sir Michael Wood argued, while for Bangladesh Lawrence Martin, Philippe Sands, Payam Akhavan, Paul Reichler, Alan Boyle and James Crawford.

The Permanent Court of Arbitration (PCA) gave verdict on July 07, 2014 on maritime disputes between India and Bangladesh. In a landmark judgment, the International Arbitral Tribunal rejected Indian's maritime claim and upheld Bangladesh's claim of 200 nautical miles Exclusive Economic Zone and the territorial rights in the Bay of Bangal. The verdict of the United Nations Permanent Court of Arbitration (PCA), based in The Hague, went largely in favour in Bangladesh, as it gave the country a substantial share of the extended continental shelf beyond $200 \mathrm{NM}$. The tribunal awarded Bangladesh 19,467sq km area out of the disputed 25,602 sq km leaving 6,135 sq km to India. The judgment is final and binding on both countries and cannot be appealed against. The tribunal sustained Bangladesh's claims of equitable solution to a full 200 nautical miles Exclusive Economic Zone in the Bay and to a substantial share of extended Continental Shelf beyond 200 nautical miles.

5.2. Bangladesh's Benefits on the Basis of Judgment

Bangladesh now legally possess $118,813 \mathrm{sq} \mathrm{km}$ of air space, waters, subsed and subsoil comprising Territorial Sea, Contiguous Zone and Exclusive Economic Zone extending out to 200 nautical miles after peaceful settlement of Bangladesh- Myanmar and Bangladesh-India maritime boundaries. This paves the way for the economic development of this part of Bay of Bengal which will be beneficial to all the countries. The verdict has been broadly accepted by both the countries as a positive development for further consolidation of friendly relations especially given the geo-strategic / political significance of greater India Ocean region and South Asian sub-region. Moreover, the award has wide security and economic implications not only for India and Bangladesh but also for the entire Bay of Bengal region. The verdict would contribute towards establishing strategic partnerships among the nations sharing borders in the Bay. Both the countries have accepted the award as it will open the door for exploration of oil and gas in the Bay- the site of huge energy reserves. International legal experts have heailed the tribunal's encouragement to parties to exercise their sovereign rights and perform their duties under the convention with due regard to the rights of the other. The award has huge economic significance for a small state like Bangladesh. It has 
cleared the obstacles for Dhaka to open up its waters for foreign firms to explore and exploit hydrocarbons in the Bay. So long, Bangladesh's maritime disputes with India are believed to have deterred many international petroleum companies to invest in the sea-blocks previously offered by it. The ruling has confirmed Bangladesh's rights to exploit the potentially rich waters in the Bay region. The United Nations Convention on the Law of the Sea (UNCLOS) gives a nation $12 \mathrm{~nm}$ of territorial control and ensures sovereign rights to explore, exploit and manage natural resources with $200 \mathrm{~nm}$ of EEZ. Now, Bangladesh can go ahead with their plans of search and extraction of energy and mineral resources and exploitation of fisheries within $200 \mathrm{~nm}$ from baseline. Bangladesh will be able to attract international oil companies to explore the deep sea for oil and gas. We should now proceed to carry out a general seismic survey at the Bay of Bangal. Also BAPEX and Petrobangla will have to provide their competence in terms of exploring off-shore blocks for oil and gas. We have now the sovereign right to fish, mine, collect and gather any resource available within the $118,813 \mathrm{sq} \mathrm{km}$ sea. Even sea birds flying over this territory are ours. Shipwrecks are ours too, to recover and claim. Any archaeology site found in this area is ours. The verdict is also good news for millions of fishermen in both the countries. On the basis of judgement, our rights in 118,813 sq km sea have been insured conventionally. Our different rights in different sea area have been discussed below.

5.2.1 In Territorial Sea

The government may, by the notification of the official Gazette, declare the limits of the sea beyond the land territory and internal waters of Bangladesh which shall be territorial waters of Bangladesh. The sovereignty of Bangladesh extends, beyond its land territory and internal waters and, in the case of Archipelagic State, its archipelagic waters, to an adjacent belt of sea, described as the territorial sea. Bangladesh has sovereignty to exercise its legal rights to the air space, in water as well to its bed and subsoil. The sovereignty over the territorial sea is exercised subject to this convention and to the rules of international law. Bangladesh has the right to establish the breadth of its territorial sea up to a limit not exceeding 12 nautical miles, measured from baselines. Bangladesh has right of innocent passage through the territorial sea of all coastal state. Bangladesh has right to take necessary steps-

- To prevent the passage through the territorial waters of any foreign ship having no right of innocent passage;

- To prevent and punish the contravention of any law or rule in force in Bangladesh by any foreign ship exercising the right of innocent passage;

- To prevent the passage of any foreign warship without previous permission of Government; and

- To prevent and punish any activity which is prejudicial to the security or interest of the Republic.

In accordance with the article 27 of UNCLOS III of 1982, Bangladesh as a coastal state has rights to arrest any person or to conduct any investigation in connection with any crime committed on board of foreign ship passing during its passage through the territorial sea in the following cases:

- If the consequences of the crime extend to the coastal state;

- If the crime is of kind to disturb the peace of the country or the good order of the $t$ territorial sea;

- If the assistance of the local authorities has been requested by the master of the ship or by diplomatic agent or consular officer of the flag state; or

- If such measures are necessary for the suppression of illicit traffic in narcotic drugs or psychotropic substances.

The above provisions do not affect the right of the coastal state to take any steps authorized by its law for the purpose of an arrest or investigation on board a foreign ship passing through the territorial sea after leaving internal waters. According to the article 28(2) of UNCLOS III of 1982, Bangladesh has right of civil jurisdiction to execute against or arrest the ship for the purpose of any civil proceedings in respect of obligations or liabilities assumed or incurred by the ship itself in the course or for the purpose of its voyage the waters of the coastal state. This provision does not affect the right of the coastal state to take any steps authorized by its laws to execute against or to arrest , for the purpose of any civil proceedings, a foreign ship lying in the territorial sea, or passing through the territorial sea after leaving internal waters.

5.2.2 In Contiguous Zone

The contiguous zone is a zone of sea contiguous to and beyond the territorial sea in which Bangladesh has limited powers for the enforcement of customs, fiscal, sanitary and immigration laws. The contiguous zone may not extend beyond 24 nautical miles from the baselines from which the breadth of the territorial sea is measured. That is to say, it is twelve miles beyond the territorial sea. According to the article 33 of UNCLOS III, Bangladesh has rights to enact laws and regulations about customs, fiscal, immigration and sanitary within its territory or territorial sea. Bangladesh has rights to exercise the control necessary to prevent infringement of its customs, fiscal, immigration or 
sanitary laws and regulations within its territory or territorial sea. Bangladesh has also rights to punish infringement of the above laws and regulations within its territory or territorial sea.

5.2.3 In Exclusive Economic Zone

According to the article 55 of UNCLOS III, The Exclusive Economic Zone is an area beyond and adjacent to the Territorial Sea, subject to the specific legal regime established under part 5, under which the rights and jurisdiction of the coastal state (Bangladesh) are governed by the relevant provision of this convention. According to the article 57 of UNCLOS III, The Exclusive Economic Zone shall not extend beyond 200 nautical miles from the base lines from which the breadth of the territorial sea is measured. On the basis of judgement with India and Bangladesh (2014) and with Myanmar and Bangladesh (2012), 200 nautical miles exclusive economic zone from baselines has been ensured for Bangladesh in the Bay of Bangal. Now, Bangladesh shall freely enjoy her rights in the Exclusive Economic Zone. According to the article 56 of UNCLOS iii, Bangladesh has sovereign rights for the purpose of exploring and exploiting, conserving and managing the living and nonliving resources of the sea bed and subsoil and the superjacent waters. Furthermore, this right is to be exercised in accordance with the provisions of UNCLOS iii relating to the continental shelf. The non-living resources of the superjacent waters relates to the various minerals which can be extracted from sea water. Bangladesh has sovereign rights with regard to other activities for the economic exploitation and exploration of the zone such as the production of energy from the waters, currents and winds. This provision gives Bangladesh quite new rights and reflects and is phrased so as to permit Bangladesh to take advantage of developments in technology. The production of energy will usually require the construction of installations of some kind (e.g. wave barrages). In respect of this and the following two rights the UNCLOS iii confers on Bangladesh not sovereign rights (as with the first three rights) but the more limited jurisdiction. Article 56 of UNCLOS iii provides that Bangladesh has jurisdiction as provided for in the relevant provisions of this convention with regard to the establishment and use of artificial island, installations and structures. The relevant provisions referred to are to be found in article 60 . This article gives Bangladesh:

The exclusive right to construct and to authorize and regulate the construction, operation and use of;

- Artificial island;

- Installations and structures for the purposes provided for in article 56 and other economic purposes;

- Installations and structure which may interfere with the exercise of the rights of Bangladesh in the zone.

Article 56 of UNCLOS iii gives Bangladesh jurisdiction as provided for in the relevant provisions of this convention with regard to marine scientific research. The relevant provisions of this convention are to be found in part XIII. Article 246(1) of UNCLOS iii provides that the coastal state (Bangladesh) has the right to regulate, authorize and conduct scientific research in its EEZ. Article 56 confers on Bangladesh jurisdiction as provided for in the relevant provisions of this convention with regard to the protection and preservation of the marine environment. The relevant provisions of the convention are to be found in part XIII. This part gives Bangladesh legislative and enforcement competence in its EEZ to deal with the dumping of waste (LOSC. Articles 210 (5) and 216 other forms of pollution from vessels (LOSC. Articles. 211 (5-6). 220. 234 and pollution from sea bed activities (LOSC.arts.208.214).

5.2.4 In Continental Shelf

The judgment between India and Bangladesh (2014) has ensured for Bangladesh more than 1, 18,813 sq km of waters comprising Territorial Sea, Exclusive Economic Zone and also undeniable sovereign rights in the sea bed and subsoil extending as far as 354 nautical miles from the Chittagong coast in the Bay. Bangladesh can exercise over the continental shelf sovereign rights for the purpose of exploring it and exploiting its natural resources according to the article 77(1) of UNCLOS iii. According to the article 77(4) of UNCLOS iii, Natural resources mean the mineral and other non-living resources of the sea bed and subsoil together with living organisms belonging to the sedentary species, that is to say, organisms which, at the harvestable stage, either are immobile on or under the sea bed or are unable to move except in constant physical contact with the sea bed or the sub soil. Bangladesh has legal status of the superjacent waters or of the air space over the continental shelf. According to the article 79, 80 and 81 of UNCLOS iii, Bangladesh is entitled to lay submarine cables and pipelines on the continental shelf. Bangladesh has right to establish artificial island, installations and structures on the continental shelf. Bangladesh shall have the exclusive right to authorize and regulate drilling on the continental shelf for all purposes. According to the article 7(4) of The Territorial Waters and Maritime Zones Act 1974, The Bangladesh government may construct, maintain or operate within the continental shelf installation other devices necessary for the exploration and exploitation of its resources. According to the article 111 of UNCLOS iii, Bangladesh has right of hot pursuit to the foreign ship or one of its boats is within the internal waters, the archipelagic waters, the territorial sea or the contiguous zone of the pursuing state (Bangladesh), and may only be continued outside the territorial sea or the contiguous zone if the pursuit has not been interrupted. If the foreign ship is within a contiguous zone, as defined in article 33, the pursuit may only be undertaken if there has been a violation of the rights for the protection of which the zone was established. According to the article 111(2) of UNCLOS iii, the right of hot pursuit shall apply mutatis mutandis to 
violations in the exclusive economic zone or the continental shelf, such safety zones. According to the article 111(4) of UNCLOS iii, the pursuit may only be commenced after a visual or auditory signal to stop has been given at a distance which enables it to be seen or heard by the foreign ship.

\section{Recommendation}

6.1 On Territorial Sea

The government may declare the limits of the sea beyond the land territory and internal waters of Bangladesh which shall be the Territorial Sea of Bangladesh specifying the notification the baseline.

- From which such limits shall be measured; and

- The waters on the land ward side of which shall form part of the internal waters of Bangladesh.

Where a single island rock or a composite group there of constituting the part of the territory of Bangladesh is situated seawards from the main coast or baseline, Territorial Sea shall extend to limits declare by notification measured from the low waterline along the coast of such island, rock or composite group. The sovereignty of the republic extends to the territorial waters as well as to the air space over and the bed and of such waters. No foreign ship shall unless it enjoys the right of innocent passage, pass through the territorial waters.

\subsection{On Contiguous Zone}

The zone of high sea contiguous to the territorial waters and extending seawards to a line 06 nautical miles measured from the outer limits of the territorial water is hereby declared to be the Contiguous Zone of Bangladesh (according to the Territorial Waters and Maritime Zones Act 1974). And now Bangladesh may establish 24 nautical miles of Contiguous Zone as against 06 nautical miles which declared under the Act of 1974. The government may exercise such powers and take such measures in or respect of the contiguous zone. As it may consider necessary to prevent and punish the contravention of an attempt to contravene any law or regulations in force in Bangladesh relating to the security of the republic, the immigration and sanitation, and custom and other fiscal matters.

6.3 On Exclusive Economic Zone

The Government may, by notification in the official Gazette, declare any zone of high seas adjacent to the Territorial Sea to be the Exclusive Economic Zone of Bangladesh specifying there in the limit of the zone from baseline to 200 nautical miles ( according to 1982 convention). All natural resources within the Exclusive Economic Zone, both living and non living on or under the seabed and subsoil or on the water surface or within the water column shall vest exclusively in the republic. Nothing shall be dressed to be the affect fishing within the Exclusive Economic Zone by a citizen of Bangladesh or any other state. .

6.4 On Continental Shelf

A Continental Shelf is that zone, where every state can use it for their own purposes. It is the area beyond high sea. Therefore, it is the place is not under control of any state. But to avoid certain difficulties government may, by notification in the official Gazette, specific the limits there of. No person shall except permission in accordance with the terms of a license or permission granted by the Government explore or exploit any resources of the continental shelf or carry out any search or excavation or conduct any research with the limit of the continental shelf.

The government may with a view preventing and controlling marine pollution and preserving the quality and geological balance in the marine environment in the high seas adjacent to the territorial coasters, take such measures as it may dress appropriate for the purpose. The Government may make rotes for carrying out the purpose of this Act in particular and without prejudice to the generality of the foregoing power, such rotes may provide.

- For the regulation of the conduct of any person in and upon the territorial coaters, contiguous zone, conservation and continental shelf.

- For measures to protect, use and exploit the resources of the Exclusive Economic Zone.

- For conservation measures to protect the living resources in the sea.

- For measures regulating the exploration and exploitation of resources within the Continental shelf.

- For measures designed to prevent and control of marine pollution of the high sea.

\section{Conclusion}

In the light of the latest maritime verdict, our responsibilities for controlling our portion of the Bay have increased. Effective, responsible and coordinated efforts of the concerned authorities are needed for protecting our maritime boundary and its living and nonliving natural resources. Because it is not needed to pay or contribute to The International Sea-bed Authority for any productions from the territorial sea to open sea within five years. For the six year, the rate of payment or contribution shall be 1 percent of the value or volume of production at the site. The rate shall increase by 1 percent for each subsequent year until the twelfth year and shall remain 7 percent thereafter. So, we must move forward dynamically to explore, exploit, conserve and manage all kinds of living and nonliving natural resources in our different sea area. 
References

Churchill, R.R.and Lower, A.V. (1983) The Law of the Sea, Manchester University Press.

Faruque, A A. (2009). Essentials of Legal Research, Palal Prokashani, Dhaka.

Halim, A. (2008). The Legal System of Bangladesh, University Publications, Dhaka.

Halim, A. (2008). The Legal System of Bangladesh after Separation, University Publications, Dhaka.

Houghton, K. J., Vafeidis, A. T., Neumann, B., \& Proelss, A. (2010). Maritime boundaries in a rising sea. Nature Geoscience, 3(12), 813.

ITLOS, 'Disputes Concerning Delimitation of the Maritime Boundary between Bangladesh and Myanmar' in the Bay of Bangal', the Bangladesh v Myanmar case, 14 March 2012.

Kapoor S K. (2004) International Law and Human rights, 15th ed. (India: Central Law Agency).

Monzur Kader, Dr. (2007) The Law of the Sea, Shams Publication, Dhaka.

PCA.(2014) 'Disputes Concerning Delimitation of the Maritime Boundary between Bangladesh and India' in the Bay of Bangal', the Bangladesh v India case

Rupak Bhattacharjee. (2014) Delimitation of Indo-Bangladesh Maritime Boundary.

Rahman, M. H. (1984). Delimitation of maritime boundaries: a survey of problems in the Bangladesh case. Asian survey, 24(12), 1302-1317.

Statutory Law, 'The Territorial Waters and Maritime Zones Act, 1974',Bangladesh, entered into force on 4th February ,1974.

Tewari, H N. (2004). Legal Research Methodology, Ahhahabad Law Agency, Haryana, India.

The United Nations, 'The Third United Nations Convention on the Law of the Sea', did on 10 December 1982 in Montego Bay, Jamaica, entered into force on 16 November, 1994.

Website:www.pca-cpa.org

Copyrights

Copyright for this article is retained by the author(s), with first publication rights granted to the journal.

This is an open-access article distributed under the terms and conditions of the Creative Commons Attribution license (http://creativecommons.org/licenses/by/4.0/) 